\title{
The Effect of Drying Processes on the Nutritional and Phytochemical Levels of Chia Leaves (Salvia hispanica L.) at Different Stages of Growth
}

\author{
Jackline S. Kirruti, Monica W. Mburu, and Daniel M. Njoroge
}

\section{ABSTRACT}

Chia leaf (Salvia hispanica L.) is an underutilized low-cost source of nutrients. The leaf is currently not widely utilized as compared to the chia seeds which have wide use in the food industry. The present study investigated the effect of solar-drying and oven-drying chia leaves harvested at different stages of growth on their nutritional and phytochemical composition. The chia leaves were harvested at four stages of early vegetative stage, late vegetative stage, budding stage and flowering stage. Oven drying was done at $45^{\circ} \mathrm{C}$ for 24 hours, and solar dried in a solar drier until a constant weight was achieved. The results indicated significant differences $(p<0.05)$ between treatments and stages of maturity. Results also showed that solar dried had better nutritional and phytochemical retention over oven dried chia leaves. Crude protein was highest in solar dried leaves at early vegetative stage (FS1) $4.48 \%$, compared to $4.44 \%$ for oven dried chia leaves. The fiber content increased from the fresh leaf at $12.4 \%$ to high content in solar dried leaf at the early vegetative stage at $23.33 \%$, while oven dried leaves had high content at the flowering stage at $\mathbf{2 2 . 0 9 \%}$. There were minimal changes in fat content of the dried chia leaves compared to fresh sample at $5.908 \%$, with high fat levels noted for oven dried leaf at the early vegetative stage (FS3) at $5.68 \%$ and solar dried leaves at $4.71 \%$ at the budding stage. The difference in fat content could be attributed to degradation during the drying processes. Ash content on the other hand showed difference at different stages of growth from raw samples for both solar- and oven dried leaves. Highest retention of phenolic content was recorded at $147.62 \mathrm{mg} / \mathrm{GAE}$ for solar dried leaves at the budding stage (FS3). However, oven dried leaf samples recorded high phenolic content at 124.06 $\mathrm{mg} / \mathrm{GAE}$ at the late vegetative stage. The flavonoid levels were recorded highest for solar dried leaves at the budding stage at $299.8 \mathrm{mg} / \mathrm{CE}$, compared to high content for oven dried leaves at the budding stage recorded at $\mathbf{2 7 0 . 4}$ $\mathrm{mg} / \mathrm{CE}$. Scavenging activity was highest recorded for solar dried samples at the budding and flowering stages at $100 \mu \mathrm{g} / 100 \mathrm{~g}$ compared to oven dried leaves at $80.85 \mu \mathrm{g} / \mathrm{100g}$ at the late vegetative stage. Solar drying is the simplest and convenient low-cost technology for preserving the nutritional quality and retention of phytochemical ranges of chia leaves which will enhance their utilization when abundantly available.

Keywords:Chia leaves, nutrient retention, oven-drying, phytochemicals, solar drying.
Submitted : November 08, 2021

Published : December 16, 2021

ISSN: $2684-1827$

DOI: 10.24018 /ejfood.2021.3.6.413

Jackline S. Kirruti*

Institute of Food Bioresources, Dedan Kimathi University of Technology, Dedan Kimathi, Nyeri, Kenya.

(e-mail:jackykirruti@gmail.com)

Monica W. Mburu

Institute of Food Bioresources, Dedan

Kimathi University of Technology, Dedan Kimathi, Nyeri, Kenya.

(e-mail: monica.mburu@dkut.ac.ke) Daniel M. Njoroge

Institute of Food Bioresources, Dedan Kimathi University of Technology, Dedan Kimathi, Nyeri, Kenya.

(e-mail: Daniel.njororoge@ dkut.ac.ke)

*Corresponding Author: Jackline Kirruti

\section{INTRODUCTION}

Leafy vegetable sources are important to food and nutrition security and play a role in addressing gaps in nutrient demands among majority of population worldwide. Plant based dietary sources have been found to have biochemical components and more so phytochemicals with known therapeutic benefits such as low risk of diseases [1]. Chia (Salvia hispanica L.) is a traditionally grown oil seed crop in pre-Colombian Centra America, whose cultivation and utilization had almost gone to oblivion but new interest as new and functional food has grown in recent years[2], [3]. Chia seed is the widely used food source as it is a natural source of omega- 3 fatty acid, proteins, fiber and important vitamins and minerals[4]. However, the nutritional composition and use of chia leaves has not been the subject of many studies. Chia leaves, unlike chia seeds, remain unexplored their potential as an alternative, therapeutic and nutritious food source and raw material for the industry. Past studies have identified in the chia leaf polyunsaturated fatty acids, protein, vitamins, minerals and beneficial phytochemicals [3]. Constraints to wider utilization of chia leaves are their high perishability and loss of nutrients during storage.

To curb the perishability of leafy vegetables, preservation methods need to be applied, which prolong the shelf without compromising their nutritional properties[5]. Drying of leafy vegetables is the common practice to remove excess water 
content to delay enzymatic and microbiological degradation[6]. Various technologies used in drying of leafy vegetables which include solar drying, vacuum drying, oven drying and freeze drying[7], though their use has been associated with negative effects such as loss of flavor, discoloration, and texture loss[6]. Solar drying is most common and simplest, affordable and accessible means for most smallholder farmers in sub-Saharan Africa[8]. Though cheap, solar drying has been reported to cause high nutritional losses, whilst requiring longer periods to achieve the requisite moisture level and weight[9]. An alternative is oven drying which has been shown to have minimal nutritional losses such as carotenes, while improving the sensory attributes of color and tastes of vegetables[10]. Oven drying however is expensive and is constrained by availability of a power source[7]. The choice of drying method and optimization of the process is essential in maintaining essential nutritional and sensory properties of leafy vegetables [11].

Presently, there is limited literature elucidating application of drying methods and their effects on chia leaves and seeds. Most studies are based on the nutritional and bioactive components and utilization of chia seeds and leaves, with minimal work on drying methods used and their resultant effects.Few studies have investigated effect of drying processes for various food applications. For instance, [12]studied the effect of drying processes of oven and freezedrying on chia mucilage in developing films for use in food packaging. In addition,[13]isolated protein from chia seeds and converted to a powder by use of freeze and vacuum drying methods and investigated their effect on physicochemical of the resultant protein isolate formed. Information on chia leaves regarding effect of drying process on nutritional and bioactive elements remains scanty. The present study therefore, was undertaken to determine the effect of drying methods on the nutritional and bioactive compounds such as phenolic acids, flavonoids and antioxidant activity of chia leaves harvested at different stages of growth.

\section{MATERIAL AND METHODS}

\section{A. Materials}

Chia seeds were obtained from the Dekut Chia demonstration farm. Planting plots were prepared $5.0 \mathrm{~m}$ long by $2.5 \mathrm{~m}$ wide with $0.5 \mathrm{~m}$ between rows. The seeds were sown by hand at $1 \mathrm{~cm}$ depth. The plants were evaluated after every 3 days to determine their phenological stages of growth. The plants were harvested from the same plant at four developmental stages (early vegetative, late vegetative, budding and flowering). The harvested leaves were washed with clean to remove debris and reduce microbial load. After dividing the leaves into two halves, one portion was dried using a solar dried unit to obtain an uniform weight. The other portion was dried in an oven at $45^{\circ} \mathrm{C}$ for 24 hours. The sample were then stored in airtight bags at $4{ }^{\circ} \mathrm{C}$ for further analysis.

\section{B. Experimental Design}

The study was set up in completely randomized design, where the chia (salvia hispanica L.) leaves were planted and harvested leaves at four different stages of growth. The harvested chia leaves were subjected to solar drying and oven drying after which the samples were stored in airtight bags at $4{ }^{\circ} \mathrm{C}$ for further analysis.

\section{Moisture Content Analysis}

Moisture content was determined by the AOAC method 967.03. $2 \mathrm{~g}$ of the sample was weighed in a moisture dish and both their weights taken. These were placed in the air-oven and temperatures set at $105^{\circ} \mathrm{C}$ and then allowed to dry for 3 hours. The samples were removed and cooled in a desiccator. The final weight was obtained after cooling from which a constant weight was obtained. Moisture was calculated as:

\section{Moisture \% = \\ $\frac{\text { Weight of original Sample }(\mathrm{g})-\text { Weight of dried sample }(\mathrm{g})}{\text { Weight of original sample }(\mathrm{g})} \times 100(\mathrm{~g})$ \\ Dry Matter Content $=\frac{\text { Weight of Dry Sample }(\mathrm{g})}{\text { Weight of original sample }(\mathrm{g})} \times 100(\mathrm{~g}$}

\section{Protein Content Analysis}

The protein content was determined as per the method by [14] with modifications. $0.1 \mathrm{~g}$ of the sample was digested, neutralized and titrated with $0.1 \mathrm{M} \mathrm{HCl}$. Protein content was determined as:

$$
\text { Kjeldhal nitrogen }(\%)=\frac{\mathrm{T} \times 14.01 \times \mathrm{M}}{\mathrm{W} \times 10}
$$

where

$\mathrm{T}=$ titre value $(\mathrm{ml}$;

$\mathrm{W}=$ sample weight $(\mathrm{g})$;

$\mathrm{M}=$ molar concentration $(\mathrm{moles} / \mathrm{L})$ of the acid $(\mathrm{HCl})$;

$14.01=$ atomic weight $(\mathrm{g})$ of $\mathrm{N}$;

$10=$ factor to convert $\mathrm{mg} / \mathrm{g}$ to percent.

Crude protein content $(\%)=\%$ Kjeldhal nitrogen $\times 6.25$

where $6.25=$ factor to convert $\mathrm{N}$ to protein.

\section{E. Fibre Content Analysis}

Fibre content was determined by the AOAC method 973.18. $2 \mathrm{~g}$ of the sample the samples were defatted and then hydrolyzed with $1.25 \% \mathrm{H}_{2} \mathrm{SO}_{4}$. An aliquot $(190 \mathrm{ml})$ of boiling $\mathrm{H}_{2} \mathrm{SO}_{4}$ was added into the flask and mixed properly such that a cream was produced. . This flask was equipped with a reflux condenser and heated prior to its contents being quickly emptied into a shallow layer of hot water enclosed within a hot Buchner funnel prepared with wet $12.5 \mathrm{~cm}$ filter paper. Suction filtration was used, and the suction rate was set so that filtration processwas finished within 10 minutes. The residue was rinsed with hot distilled water to remove any remaining acid and quantitatively placed into a $100 \mathrm{ml}$ volumetric flask with $200 \mathrm{ml}$ of boiling 1.25 percent $\mathrm{NaOH}$ solution. After 30 minutes of refluxing, the filtrate was allowed to cool for a minute before being filtered under suction. The residue was washed many times with boiling (distilled) water, followed by $1 \% \mathrm{HCI}$, and finally with boiling water until the wash was acid free. Additionally, two washes with ethanol and two with petroleum ether were 
performed. The residue was placed quantitatively and gently (using a clean spatula) into a weighted crucible and dried for one hour at $105^{\circ} \mathrm{C}$. After cooling in a desiccator, it was weighed. After that, the dried residue was put in a furnace set at $630^{\circ} \mathrm{C}$ for 3 hours. The crude fiber content was determined, as well as the crude fiber percentage. To determine the weight of the fibre, the ash was removed from the residual. This procedure was repeated for triplicate samples. Fibre content was calculated as:

$$
\text { Fiber content }(\%)=\frac{\text { Weight of fibre }}{\text { Weight of sample }} \times 100
$$

\section{F. Lipid Content Analysis}

Lipid content was determined as per the AOAC method 920.39. $3 \mathrm{~g}$ of powdered leaves were dried in an oven at $100{ }^{\circ} \mathrm{C}$ for 1 hour. The dried leaves were inserted in an extraction thimble and fitted in a Soxhlet apparatus which was outfitted with pre-weighed empty round bottomed flasks. The samples were defatted with $300 \mathrm{ml}$ anhydrous petroleum spirit for 16 hours, after which the solvent was distilled off, and the flask containing the lipid content allowed to cool in a desiccator. Lipid content was calculated as:

$$
\begin{aligned}
& \text { Crude lipid content (\%) } \\
& \qquad=\frac{\mathrm{W} 2-\mathrm{W} 1}{\text { Weight }(\mathrm{g}) \text { of the sample used }} \times 100
\end{aligned}
$$

where

$\mathrm{W} 1=$ weight $(\mathrm{g})$ of empty flask;

$\mathrm{W} 2=$ weight $(\mathrm{g})$ of flask and lipid.

\section{G. Mineral Content Analysis}

Specific mineral contents were determined by the AOAC method (2005). $2 \mathrm{~g}$ of the sample were placed in a muffle furnace at $600^{\circ} \mathrm{C}$ and ashed for 7 hours. The resultant ash was dissolved in $2 \mathrm{~N} \mathrm{HNO}_{3}$ in a volumetric flask and topped up $100 \mathrm{ml}$ distilled water. The amount of Magnesium, potassium, calcium, and zinc were determined using an Atomic Absorption Spectrophotometer (Zeenit 650P).Standard solutions of $\mathrm{Mg}, \mathrm{K}, \mathrm{Ca}$ and $\mathrm{Zn}$ were prepared and used in preparation of a calibration curve.

Concentration of the minerals was calculated as:

$$
\mathrm{A}\left(\frac{\mathrm{mg}}{100} \mathrm{~g}\right)=\frac{100}{W} \times \frac{C}{1000} \times D
$$

where

A= element being determined;

$\mathrm{W}=$ weight of sample used;

$\mathrm{C}=$ concentration in ppm obtained from the standard curve; $\mathrm{D}=$ dilution factor applied.

The phosphorus level was evaluated using the vanadomolybdate colorimetric technique and a reference solution of potassium phosphate. First, $50 \mathrm{ml}$ of material was pipettedinto a $125 \mathrm{ml}$ Erlenmeyer flask along with a drop of phenolphthalein indicator. $8 \mathrm{ml}$ of the combined reagent $(5 \mathrm{~N}$ sulphuric acid, ammonium molybdate, and $0.1 \mathrm{M}$ ascorbic acid) was added and carefully mixed. After ten minutes, the absorbance was measured at $880 \mathrm{~nm}$ using a blank solution as the reference solution. All measurements were made in triplicate.

\section{H. Total Phenolic Content}

The total Phenolicconcentration was determined using techniques by[14] with adjustments. $0.5 \mathrm{~g}$ of the sample were obtained with $10 \mathrm{ml}$ of $80 \%$ methanol and centrifuged at 4000 rpm for 10 minutes. The supernatant was combined, and $0.5 \mathrm{ml}$ of the extract was combined with $1.5 \mathrm{ml}$ FolinCiocalteu reagent and neutralized with $3 \mathrm{ml}$ of $\mathrm{Na}_{2} \mathrm{CO}_{3}$ solution $(7 \% \mathrm{w} / \mathrm{v})$. A UV-Visible spectrophotometer wasset at $725 \mathrm{~nm}$ and used to analyze the blue complex formed. A standard curve was constructed using gallic acid (1, 10, 20, $40,60,80$, and $100 \mathrm{~g} / \mathrm{ml}$ ), and total phenolics were expressed as $\mathrm{mg} / \mathrm{g}$ Gallic acid equivalent (GAE) of dry extract.

$$
\begin{aligned}
& \text { Total phenolics in mg GAE per g of dry sample } \\
& \qquad=\frac{\text { C XDFX100 }}{\text { WX1000 }}
\end{aligned}
$$

where

$\mathrm{C}=$ Concentration obtained from the calibration in $\mu \mathrm{g} / \mathrm{ml}$;

$\mathrm{D}=$ Total dilution factor;

$\mathrm{W}=$ weight of the sample in grams;

$100=$ Conversion factor to report results in $\mathrm{mg} / 100 \mathrm{~g}$;

$1000=$ conversion from $\mu \mathrm{g} / \mathrm{ml}$ to $\mathrm{mg} / \mathrm{ml}$.

\section{Flavanoid Content}

The total flavonoids content was determined using a modified version of the method described by [14]. In this method, $0.5 \mathrm{~g}$ of chia leaf samples were extracted with $10 \mathrm{ml}$ of $80 \%$ methanol, centrifuged at $4000 \mathrm{rpm}$ for 10 minutes, and the supernatants pooled. $1 \mathrm{ml}$ of the extract was combined with $1.5 \mathrm{ml}$ of $80 \%$ methanol, $0.5 \mathrm{ml}$ of $10 \%$ aluminum chloride, 0.5 milliliters of $5 \%$ sodium nitrite, $4 \mathrm{ml}$ of $2 \mathrm{M}$ $\mathrm{NaOH}$, and 4 milliliters of distilled water. After 30 minutes of incubation, the samples were measured for absorbance at $510 \mathrm{~nm}$ using a UV-visible spectrophotometer. The standard curve was constructed using catechin at concentrations ranging from 0 to $100 \mathrm{~g} / \mathrm{ml}$, and total flavonoids were expressed as mg Catechin equivalents (CE) per gram of dry sample.

Total flavonoid in mg CE per mg of dry sample

$$
=\frac{\mathrm{C} \times \mathrm{DF} \times 100}{\mathrm{~W} \times 1000}
$$

where

$\mathrm{C}=$ concentration obtained from the calibration in $\mu \mathrm{g} / \mathrm{ml}$; $\mathrm{DF}=$ total dilution factor.

\section{J. DPPH Antioxidant Activity}

The free radical scavenging activity of the chia leaves extract was determined as per the method by[14] with modifications. $0.5 \mathrm{~g}$ of the chia leaves samples were extracted with $10 \mathrm{ml}$ of $80 \%$ methanol and centrifuged at $4000 \mathrm{rpm}$ for 10 minutes and the supernatants pooled together. Thecrude extractsof $1 \mathrm{~mL}$ at different concentrations $(0,5,10,20,30$, 40 and $50 \mu \mathrm{g} / \mathrm{mL}$ ) were taken in separate test tubes. $0.2 \mathrm{~g}$ of DPPH was dissolved in $100 \mathrm{Ml}$ of absolute ethanol, wrapped with aluminumfoil and kept at $-18{ }^{\circ} \mathrm{C}$. $50 \mu \mathrm{L}$ DPPH radical solution was added to each test tube with standard and the 
samples. The solution was immediately mixed and left to stand for 30 minutes in the dark at room temperature. Without extract or ascorbic acid, a blank was made in a similar manner. Each solution's absorbance was measured at $515 \mathrm{~nm}$ using a UV-Vis spectrophotomer. The percentage of radical scavenging activity of the extracts and the positive control ascorbic acid will be computed, and the findings will be given in $\mathrm{mg}$ of ascorbic acid equivalent per $100 \mathrm{~g}$ of dry material.

Total antioxidant activity in mg of ascorbic acid
equivalent per $100 \mathrm{~g}$ of dry sample $=\frac{\text { X XDX100 }}{\text { WX1000 }}$

where

$\mathrm{C}=$ Concentration obtained from the calibration in $\mu \mathrm{g} / \mathrm{ml}$; $\mathrm{DF}=$ Total dilution factor;

$100=$ Conversion factor to report results in $\mathrm{mg} / 100 \mathrm{~g}$;

$\mathrm{W}=$ weight of the sample in grams;

$1000=$ conversion from $\mu \mathrm{g} / \mathrm{ml}$ to $\mathrm{mg} / \mathrm{ml}$.

\section{RESULTS}

\section{A. Effect of Drying Process on the Biochemical Composition of Chia Leaves}

The biochemical composition of the chia leaves at different developmental stages and drying method are as shown in Table I. The stage of growth and drying method had a significant effect $(\mathrm{p}<0.05)$ on the chia leaves biochemical composition. Moisture content varied significantly $(\mathrm{p}<0.05)$ in drying method and stage of growth with values ranging between $9.19 \% \mathrm{DM}$ to $12.53 \% \mathrm{DM}$. The oven dried chia leaves had moisture content values ranging between $9.19 \%$ DM to $12.53 \%$ and solar dried leaves between $9.84 \%$ DM to $11.07 \%$ DM \%.High moisture content was noted for oven dried at late vegetative stage (FO2) chia leaves at $12.53 \%$. The trend indicates reducing moisture levels with the growth period from vegetative to flowering stage with the late vegetative stage recording high moisture values.

The protein content values ranged between $3.221 \%$ to $4.444 \%$ for oven dried leaves, and $3.250 \%$ and $4.477 \%$ content for solar dried leaves. Thecrude protein trends reduced significantly $(p<0.05)$ reduced from the first developmental stage to the last in solar dried samples. Crude protein was highest in solar dried sample at early vegetative stage(FS1) $4.48 \%$ lowest in solar dried sample at flowering stage(FS4) $3.25 \%$. The trend shows reducing crude protein levels with later growth period of the chia leaves. The drying methods did not affect the crude protein levels at corresponding stage of growth of the chia leaves.

The fat content varied significantly $(\mathrm{p}<0.05)$ with oven dried leaves ranging between $4.132 \% \mathrm{DM}$ and $5.678 \%$ while solar dried samples fat content ranged between $2.928 \% \mathrm{DM}$ to $4.124 \%$ DM. The trend was non-linear, however, the oven dried, early vegetative sample FO1 recorded high fat content $(5.678 \%)$ contrasted with solar dried samples where the sample FS3 at budding stage had the highest fat content (4.713\%)

Crude fibre content of the leaves as outlined in Table Ishows significant differences $(p<0.05)$ in drying methods and stage of growth of the leaves. The oven dried samples showed crude fibre content ranging between $17.09 \% \mathrm{DM}$ and 22.09\% DM, while solar dried samples ranged between $18.49 \%$ and $23.33 \%$ DM. The trend was non-linear, however, solar dried sample at early vegetative stage(FS1) had the highest crude fibre content of $23.33 \%$ while oven dried sample at early vegetative stage(FO1) had the lowest crude fibre of $17.07 \% \mathrm{DM}$.

The mineral composition of the chia leaves at different developmental stages and drying method are as shown in Table II. The drying method and different developmental stages had a significant effect $(\mathrm{p} \leq 0.05)$ on the concentration of the minerals except for magnesium and zinc. Oven dried sample at early vegetative stage had the highest concentration of magnesium $2.14 \mathrm{mg} / 100 \mathrm{~g}$ while solar dried sample at flowering stage had the lowest concentration $1.64 \mathrm{mg} / 100 \mathrm{~g}$. Oven dried sample at budding stage had the highest concentration of calcium $1.49 \mathrm{mg} / 100 \mathrm{~g}$ while oven dried sample at early vegetative stage had the lowest concentration $0.41 \mathrm{mg} / 100 \mathrm{~g}$. Solar dried sample at early vegetative stage had the highest zinc concentration of $2.54 \mathrm{mg} / 100 \mathrm{~g}$ while oven dried sample at budding stage had the lowest concentration of $1.27 \mathrm{mg} / 100 \mathrm{~g}$.

TABLE I: BIOCHEMICAL COMPOSITION OF CHIA LEAVES AT DIFFERENT DEVELOPMENTAL STAGES

\begin{tabular}{|c|c|c|c|c|c|}
\hline \multirow{2}{*}{ Sample } & \multicolumn{5}{|c|}{ Parameter } \\
\hline & $\%$ Moisture & $\%$ Protein & $\%$ Fat & $\%$ Fibre & Ash \\
\hline \multicolumn{6}{|c|}{ Raw unprocessed Sample } \\
\hline FD1 & $83.79 \pm 0.4888^{\mathrm{e}}$ & $3.497 \pm 0.001^{\mathrm{ab}}$ & $5.908 \pm 0.04^{\mathrm{d}}$ & $12.4 \pm 0.01^{\mathrm{a}}$ & $11.41 \pm 0.44^{\mathrm{bc}}$ \\
\hline \multicolumn{6}{|c|}{ Oven Dried } \\
\hline FO1 & $10.75 \pm 1.03^{\mathrm{bc}}$ & $3.96 \pm 0.05^{\mathrm{cd}}$ & $5.678 \pm 0.31^{\mathrm{cd}}$ & $17.09 \pm 0.01^{\mathrm{b}}$ & $12.41 \pm 0.36^{\mathrm{de}}$ \\
\hline $\mathrm{FO} 2$ & $12.53 \pm 0.25^{\mathrm{d}}$ & $4.444 \pm 0.05 \mathrm{e}$ & $4.132 \pm 0.18^{\mathrm{ab}}$ & $21.11 \pm 0.82^{\mathrm{de}}$ & $11.93 \pm 0.11^{\mathrm{cd}}$ \\
\hline FO3 & $9.19 \pm 0.055^{\mathrm{a}}$ & $3.284 \pm 0.04^{\mathrm{a}}$ & $4.358 \pm 0.01^{\mathrm{bc}}$ & $19.12 \pm 0.14^{\mathrm{c}}$ & $11.69 \pm 0.09^{\mathrm{bcd}}$ \\
\hline FO4 & $9.53 \pm 0.20^{\mathrm{ab}}$ & $3.221 \pm 0.29^{\mathrm{a}}$ & $4.591 \pm 0.01^{\mathrm{bcd}}$ & $22.09 \pm 0.06^{\mathrm{e}}$ & $10.28 \pm 0.10^{\mathrm{a}}$ \\
\hline \multicolumn{6}{|c|}{ Solar dried } \\
\hline FS1 & $11.07 \pm 0.29^{c}$ & $4.477 \pm 0.01^{\mathrm{e}}$ & $2.928 \pm 0.03^{\mathrm{a}}$ & $23.33 \pm 0.38^{\mathrm{f}}$ & $13.18 \pm 0.04^{\mathrm{e}}$ \\
\hline $\mathrm{FS} 2$ & $11.01 \pm 0.50^{\mathrm{c}}$ & $4.190 \pm 0.04^{\mathrm{de}}$ & $4.124 \pm 0.04^{\mathrm{ab}}$ & $18.49 \pm 0.19^{c}$ & $11.77 \pm 0.31^{\mathrm{bcd}}$ \\
\hline FS3 & $10.17 \pm 0.41^{\mathrm{abc}}$ & $3.701 \pm 0.02^{\mathrm{bc}}$ & $4.713 \pm 0.99^{\mathrm{bcd}}$ & $19.09 \pm 0.18^{\mathrm{c}}$ & $11.01 \pm 0.28^{\mathrm{ab}}$ \\
\hline FS4 & $9.84 \pm 0.46^{\mathrm{abc}}$ & $3.250 \pm 0.00^{\mathrm{a}}$ & $3.639 \pm 0.01^{\mathrm{ab}}$ & $20.73 \pm 0.76^{\mathrm{d}}$ & $11.74 \pm 0.54^{\mathrm{bcd}}$ \\
\hline
\end{tabular}

Values are mean \pm standard deviation on dry weight basis. Means in the same column having different superscripts are significantly different $(\mathrm{p} \leq 0.05)$. FO-Oven dried, FD - Field dried FS- Solar dried,1-Early vegetative stage, 2- late vegetative stage,3-budding stage, 4-flowering stage. 
TABLE II: Mineral Composition (MG/100 ML) OF Chia LeAVES AT DifFerent DeVelopmental STAGES

\begin{tabular}{|c|c|c|c|c|c|}
\hline \multirow{2}{*}{ Sample } & \multicolumn{5}{|c|}{ Parameter } \\
\hline & $P$ & $\mathrm{~K}$ & $\mathrm{Zn}$ & $\mathrm{Ca}$ & $\mathrm{Mg}$ \\
\hline \multicolumn{6}{|c|}{ Raw unprocessed leaf sample } \\
\hline FD1 & $0.43 \pm 0.025^{\mathrm{a}}$ & $2.48 \pm 0.02^{\mathrm{a}}$ & $1.21 \pm 0.32^{\mathrm{a}}$ & $0.96 \pm 0.07^{\mathrm{b}}$ & $1.59 \pm 0.09^{\mathrm{a}}$ \\
\hline \multicolumn{6}{|c|}{ Oven dried } \\
\hline FO1 & $0.55 \pm 0.02^{\mathrm{bc}}$ & $3.26 \pm 0.04^{\mathrm{cd}}$ & $1.75 \pm 1.02^{\mathrm{a}}$ & $0.41 \pm 0.05^{\mathrm{a}}$ & $2.14 \pm 0.02^{\mathrm{b}}$ \\
\hline $\mathrm{FO} 2$ & $0.61 \pm 0.004^{\mathrm{d}}$ & $2.88 \pm 0.04^{b}$ & $1.84 \pm 0.20^{\mathrm{a}}$ & $0.93 \pm 0.05^{\mathrm{b}}$ & $2.01 \pm 0.01^{\mathrm{ab}}$ \\
\hline FO3 & $0.46 \pm 0.011^{\mathrm{a}}$ & $2.62 \pm 0.08^{\mathrm{a}}$ & $1.27 \pm 0.52^{\mathrm{a}}$ & $1.49 \pm 0.09^{\mathrm{d}}$ & $1.65 \pm 0.51^{\mathrm{a}}$ \\
\hline FO4 & $0.61 \pm 0.005^{\mathrm{d}}$ & $2.89 \pm 0.04^{b}$ & $1.89 \pm 0.79^{\mathrm{a}}$ & $1.14 \pm 0.03^{\mathrm{bc}}$ & $1.96 \pm 0.01^{\mathrm{ab}}$ \\
\hline \multicolumn{6}{|c|}{ Solar dried } \\
\hline FS1 & $0.68 \pm 0.016^{\mathrm{e}}$ & $3.39 \pm 0.03^{\mathrm{d}}$ & $2.54 \pm 0.29^{\mathrm{a}}$ & $0.98 \pm 0.04^{\mathrm{b}}$ & $1.96 \pm 0.01^{\mathrm{ab}}$ \\
\hline FS2 & $0.53 \pm 0.007^{\mathrm{bc}}$ & $3.14 \pm 0.05^{\mathrm{c}}$ & $1.99 \pm 0.50^{\mathrm{a}}$ & $1.12 \pm 0.22^{\mathrm{bc}}$ & $2.02 \pm 0.01^{\mathrm{ab}}$ \\
\hline FS3 & $0.52 \pm 0.015^{\mathrm{b}}$ & $2.69 \pm 0.02^{\mathrm{a}}$ & $1.33 \pm 0.22^{\mathrm{a}}$ & $1.34 \pm 0.06 \mathrm{c}^{\mathrm{d}}$ & $1.92 \pm 0.01^{\mathrm{ab}}$ \\
\hline FS4 & $0.57 \pm 0.031^{\mathrm{cd}}$ & $2.56 \pm 0.10^{\mathrm{a}}$ & $2.17 \pm 0.55^{\mathrm{a}}$ & $1.42 \pm 0.07^{\mathrm{d}}$ & $1.64 \pm 0.08^{\mathrm{a}}$ \\
\hline
\end{tabular}

$\overline{\text { Values are mean } \pm \text { standard deviation on dry weight basis. Means in the same column having different superscripts are }}$ significantly different $(\mathrm{p} \leq 0.05)$. FO-Oven dried, FD- Field Dried, FS- Solar dried,1-Early vegetative stage, 2- late vegetative stage,3-budding stage, 4-flowering stage, P-Phosphorous, K-Potassium, Zn- Zinc, Ca-Calcium, MgMagnesium.

\section{B. The Level of Photochemical in Chia Leaves at Diffrent Stages of Growth after Drying Process}

Phenolic contents were calculated based on the standard curve plotted $\left(\mathrm{R}^{2}=0.9979\right)$ and expressed as Gallic acid equivalent (GAE). Total phenolic content was found to be highest in solar dried sample at budding stage (FS3) $147.62 \pm 0.26 \mathrm{mg} \mathrm{GAE} / 100 \mathrm{~g}$ dry sample while lowest in oven dried sample at flowering stage (FO4) $45.36 \pm 2.46 \mathrm{mg}$ GAE/100g dry sample. Solar dried samples had high total phenolic content compared to oven dried samples (Table III).

Fig. 1 shows the comparative differences in total phenolics for the solar dried and oven dried chia leaves at different stages of growth. Significant differences in total phenolic content were observed at the budding stage of the leaves with solar driedleaves recording high phenolic content as compared to the oven dried leaves at the same stage of growth.

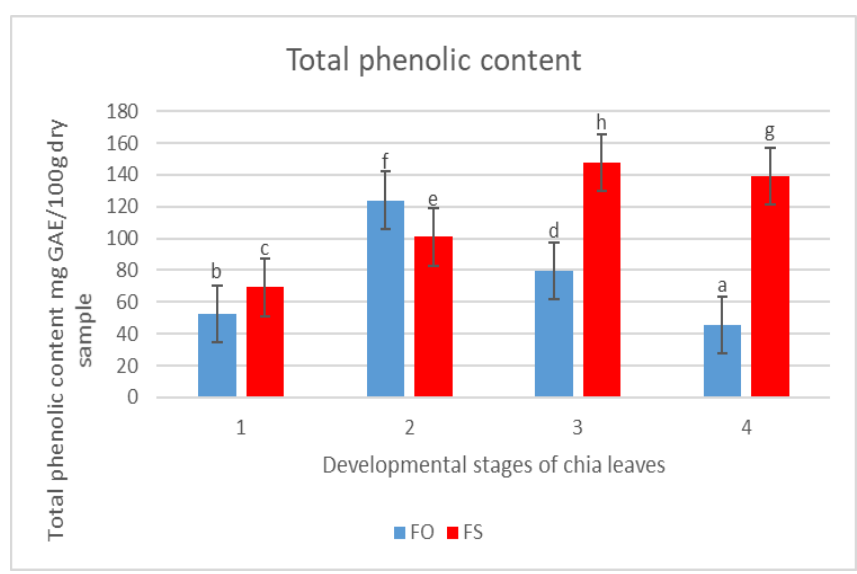

Fig.1. Total Phenol Content.

Total antioxidant activity of chia leaves was determined by testing the DPPH free radical scavenging activity and was calculated using a standard curve $\left(\mathrm{R}^{2}=0.946\right)$ and expressed as ascorbic acid equivalent (AAE). The DPPH free radical scavenging activities of solar dries samples was significantly higher in solar dried samples as compared to oven dried sample. Solar dried samples at budding and flowering stage had the highest free radical scavenging activities of $100 \mathrm{mg}$ AAE $/ 100 \mathrm{~g}$ of dries sample while oven dried sample at budding stage had the lowest free radical scavenging activity of $35.85 \mathrm{mg}$ AAE $/ 100 \mathrm{~g}$ of dried sample. There was a significant relationship between the total phenolic content and the antioxidant activity; samples with the greater phenolic content were more efficient in free radical scavenging activities.

Fig. 2 indicates the differences in scavenging activity of the chia leaves at different stages of growth. The trend shows improved scavenging activity for solar dried chia leaves as compared to the oven dried leaves. Solar dried leaves at budding stage and flowering stages had the highest scavenging activity as compared to early vegetative and late vegetative stages of growth. The oven dried leaves show an up and down trend in scavenging activity with highest activity recorded at the late vegetative stage.

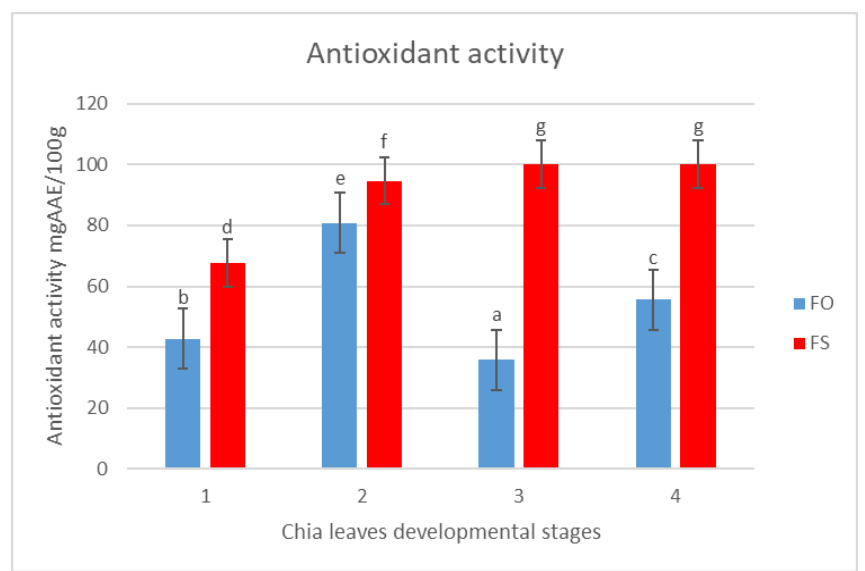

Fig.2. Antioxidant Activity.

Total flavonoids were quantified by colorimetric assay with $\mathrm{AlCl}_{3}$. Table indicates the trends in flavonoids content in the leaves. The flavonoid contents were calculated based on the standard curves plotted $\left(\mathrm{R}^{2}=0.9976\right)$ and expressed as mg Catechin equivalent per $100 \mathrm{~g}$ of dry sample. Solar dried samples budding (FS3) and flowering(FS4) stages had higher total flavonoid content of $299.8 \pm 13.14$ and $276.9 \pm 1.14 \mathrm{mg}$ $\mathrm{CE} / 100 \mathrm{~g}$ dry sample respectively while oven dried sample at early vegetative stage had the lowest total flavonoid content of $76.7 \pm 1.4 \mathrm{mg} \mathrm{CE} / 100 \mathrm{~g}$ dry sample.Fig. 3 illustrates total flavonoids for oven dried and solar dried leaves. The figure shows improved flavonoids at the late vegetative and budding stage for both oven dried and solar dried chia leaves. However, the solar dried leaves have high flavonoid content at the flowering stage as compared to the oven dried leaves. 


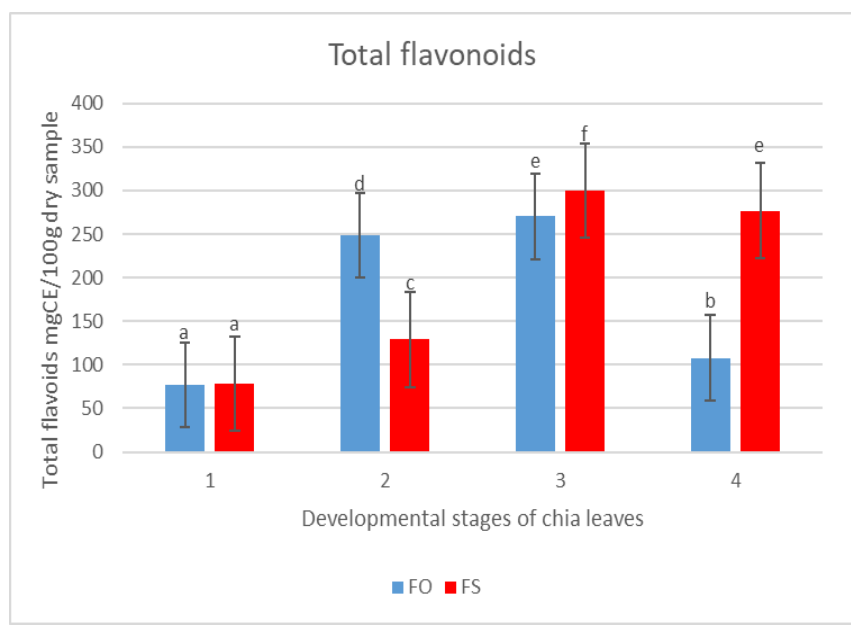

Fig.3. Total Flavanoids.

TABLE III: PHytocheMicALS OF CHIA LEAVES AT DifFERENT DEVELOPMENTAL STAGES

\begin{tabular}{cccc}
\hline \hline \multirow{4}{*}{ Sample } & \multicolumn{3}{c}{ Parameter } \\
\cline { 2 - 4 } & $\begin{array}{c}\text { Total Phenolics } \\
(\mathrm{mg} / \mathrm{GAE})\end{array}$ & $\begin{array}{c}\text { Flavonoids } \\
(\mathrm{mg} / \mathrm{CE})\end{array}$ & $\begin{array}{c}\text { Scavenging activity } \\
(\mu \mathrm{g} / 100 \mathrm{~g})\end{array}$ \\
\hline \multicolumn{4}{c}{ Raw unprocessed sample } \\
FD1 & $9.45 \pm 0.13^{\mathrm{a}}$ & $0.5 \pm 0.44^{\mathrm{a}}$ & $0.12 \pm 0.09^{\mathrm{a}}$ \\
\multicolumn{3}{c}{ Oven dried samples } \\
FO1 & $52.58 \pm 0.47^{\mathrm{c}}$ & $76.7 \pm 1.42^{\mathrm{b}}$ & $42.78 \pm 0.84^{\mathrm{c}}$ \\
FO2 & $124.06 \pm 0.63^{\mathrm{g}}$ & $248.6 \pm 1.85^{\mathrm{e}}$ & $80.85 \pm 0.28^{\mathrm{f}}$ \\
FO3 & $79.6 \pm 0.34^{\mathrm{e}}$ & $270.4 \pm 3.64^{\mathrm{f}}$ & $35.87 \pm 0.21^{\mathrm{b}}$ \\
FO4 & $45.36 \pm 2.46^{\mathrm{b}}$ & $108 \pm 1.43^{\mathrm{c}}$ & $55.67 \pm 0.37^{\mathrm{d}}$ \\
\multicolumn{4}{c}{ Solar dried samples } \\
FS1 & $69.24 \pm 0.50^{\mathrm{d}}$ & $78.2 \pm 1.07^{\mathrm{b}}$ & $67.55 \pm 0.29 \mathrm{e}$ \\
FS2 & $100.96 \pm 0.22^{\mathrm{f}}$ & $128.9 \pm 0.85^{\mathrm{d}}$ & $94.67 \pm 0.38^{\mathrm{g}}$ \\
FS3 & $147.62 \pm 0.26^{\mathrm{i}}$ & $299.8 \pm 13.14^{\mathrm{g}}$ & $100 \pm 0.0^{\mathrm{h}}$ \\
FS4 & $139.13 \pm 0.63^{\mathrm{h}}$ & $276.9 \pm 1.14^{\mathrm{f}}$ & $100 \pm 0.0^{\mathrm{h}}$ \\
\hline \hline
\end{tabular}

Values are mean \pm standard deviation on dry weight basis. Means in the same column having different superscripts are significantly different $(\mathrm{p} \leq 0.05)$. FO-Oven dried, FD - Field dried FS- Solar dried,1-Early vegetative stage, 2- late vegetative stage,3-budding stage, 4-flowering stage.

\section{DISCUSSION}

\section{A. The Effect of Drying Process on the Biochemical Composition of Chia Leaves}

Phenolic contents were calculated based on the standard curve plotted $\left(\mathrm{R}^{2}=0.9979\right)$ and expressed as Gallic acid equivalent (GAE). Total phenolic content was found to be highest in solar dried sample at budding stage (FS3) $147.62 \pm 0.26 \mathrm{mg} \mathrm{GAE} / 100 \mathrm{~g}$ dry sample while lowest in oven dried sample at flowering stage (FO4) 45.36 $\pm 2.46 \mathrm{mg}$ GAE/100g dry sample. Solar dried samples had high total phenolic content compared to oven dried samples (Table III).

Fig. 1 shows the comparative differences in total phenolics for the solar dried and oven dried chia leaves at different stages of growth. Significant differences in total phenolic content were observed at the budding stage of the leaves with solar driedleaves recording high phenolic content as compared to the oven dried leaves at the same stage of growth.

Fresh leafy vegetables are known for their high nutritive and bioactive properties essential for a healthy diet [16]. The higher the nutrient retention after processing operations is considered high quality. Heat exposure, light, and oxygen influence the nutritional quality of fresh leaves during drying conditions[14]. The results for crude protein, fat, fibre and moisture show significant differences $(\mathrm{p}<0.05)$ for both oven dried and solar dried chia leaves at different growth stages. Moisture content reduced significantly with maturity for both oven dried and solar dried leaf samples when compared to fresh leaves. These observations agree with[15]who reported decreased moisture content with maturation on amaranth (Amaranthus dubius), stinging nettle (Urtica dioica) and black nightshade (Solanumscabrum) leaves.This may be attributed to structural changes in the chia leaves that lose more moisture content via transpiration and hydrolysis of stored starch content. Moisture contributes to post harvest losses by activating enzymatic and microbiological degradation[16]and exposure to heat content evaporates inherent moisture content in the leaves[15].

The protein content decreased significantly $(\mathrm{p}<0.05)$ for the solar dried leaves after the late vegetative stage and oven dried leaves after the budding stage and could be as a result of denaturation of heat-sensitive protein content.Comparative studies by[17] on drying of basil leaves by microwave and convective drying observed decreased protein content which was attributed to oxidation owed to the longer drying times exposure. In addition, as the plant matures, it utilizes stored proteins and could suggest the reduced overall protein content at the maturity stage. Similar studies by[18] on shade dried and cabin dried amaranth and black nightshade leaves found decreased protein content when compared to the fresh leaf samples.

Ash content slightly varied among the treatments, there was no significant differences $(\mathrm{p}<0.05)$ and this could be as a result of minimal loss in minerals which constitute the ash content. Across the drying methods, specific mineral of $\mathrm{P}, \mathrm{K}$, $\mathrm{Zn} \mathrm{Ca}$, and $\mathrm{Mg}$ showed improved levels from raw chia leaves, and could be attributed to moisture loss which consequently concentrated and released the mineral content[14]. Studies by[19]found high mineral content for oven-dried pumpkin leaf (Telfaria occidentalis) leaves followed by sun dried and air-dried leaves. In contrast,[17]observed reduced mineral content in dried basil leaves by microwave and convective drying and attributed the loss due to oxidation of the leaves.

Crude fibre content showed significant differences $(\mathrm{p}<0.05)$ among the treatments at different growth stages, with solar dried having averagely higher crude fibre content than the oven-dried leaves. Comparative results by[20] reported improved fibre content for sun dried moringa oleifera leaves from $3.41 \%$ to $11.96 \%$. The oven dried leaves had averagely slightly lower crude fibre content and this could be due to losses of water-soluble content components of the crude fibre. The chia plant is heralded for its fat content more so in its seeds. The fat content reduced upon solar- and oven-dried leaves both oven dried leaves having higher crude fat content as compared to the solar dried leaves. This could be due to low fat content present in chia leaves as compared to its seed. Contrary results were reported by [18]for shade dried and cabin dried amaranth and black night shade leaves. [18] dried the leaves in a cabinet dryer at $60^{\circ} \mathrm{C}$ and $50^{\circ} \mathrm{C}$, respectively.

\section{B. The Level of Phytochemicals in Chia Seed at Diffrent Stages of Growth after Drying Process}

Phenolic contents were calculated based on the standard curve plotted $\left(\mathrm{R}^{2}=0.9979\right)$ and expressed as Gallic acid equivalent (GAE). Total phenolic content was found to be 
highest in solar dried sample at budding stage (FS3) $147.62 \pm 0.26 \mathrm{mg} \mathrm{GAE} / 100 \mathrm{~g}$ dry sample while lowest in oven dried sample at flowering stage (FO4) 45.36 $\pm 2.46 \mathrm{mg}$ GAE/100g dry sample. Solar dried samples had high total phenolic content compared to oven dried samples (Table III).

Phenolic compounds are secondary plant metabolites synthesized in response to stress conditions and have been shown to play a role in prevention of some forms of cancer and cardiovascular diseases[5]. Drying leafy vegetables and other processing techniques may induce a physical and chemical change consequently affecting the phytochemical retention post-processing [21]. Studies have shown that indigenous vegetables contain substantial amounts of phytochemicals[10]. In the present study, total phenolic improved significantly for both oven dried and solar dried leaves improved from the unprocessed samples as shown in Fig. 1. Contrary observations were observed by [10] who reported reduced phenolic content for sun-dried Chinese cabbage (Brassica rapaL.).

Variation in phenolic content results for oven dried and solar dried leaves could be due to varying drying temperatures used. High phenolic content was found at the budding growth stage (147.62 GAE) for solar dried leaves which improved from raw sample $(9.45 \mathrm{GAE})$. This retention of phenolic content can be attributed to drying heat causing the chia leaf membrane to be permeable and degrading it thereby releasing complexed total phenolics. This results agree with observations by [16] who found improved phenolic for solar dried cowpea leaves. In comparison, oven dried chia leaves had lowered TPC in comparison to solar dried leaves where high TPC was recorded by sample FO2 (124.06 GAE) at the late vegetative growth stage.The decrease in phenolic content for oven dried chia leaves could be attributed to thermal degradation of phenolic compounds at elevated temperatures such as those found in oven drying method. These observations agree with[11] who recorded decrease in phenolic acid with oven dried egg plants at $60^{\circ} \mathrm{C}$. Further studies by[22]found oven drying of stinging nettle (Urtica dioica L.) leaves improved the total phenolic compounds.[9]reported decrease in phenolic content for sun dried drumstick leaves, papaya leaves and spinach. In addition,[15]noted that phenolic compounds are heat sensitive and are prone to disruption of cell wall in leafy vegetables consequently breaking down stored phenolic compounds.

Improved flavonoids and scavenging activity were observed for both solar dried and oven dried leaf samples as shown in Fig. 3. The flavonoids improved with maturity of the chia leaves from the raw leaves. These observations agree with those of [15]on amaranth (Amaranthus dubius), stinging nettle (Urtica dioica) and black nightshade (Solanumscabrum) leaves. Solar dried chia leaves had improved flavonoid content as compared to oven dried ones. Flavonoids are heat sensitive and high heat exposure leads to their loss. Thus, lower heat coefficient in solar drying, than oven-drying which has higher heat convective transfer could be attributed to high flavonoid retention in chia leaves that were solar-dried.

The antioxidant activity in plant based foods play a role in reducing in incidence of some form of cancers, heart diseases thereby their importance in human nutrition[1]. Results show improved scavenging activity for both solar- and oven-dried chia leaves. Fig. 2 shows solar dried chia leaves had improved scavenging activity as compared to oven dried leaves. This could be due to breakdown of cell structures in the leaves and minimal leaching of antioxidants in solar drying as compared to oven drying. [15]observed higher scavenging activity for leafy vegetables that were unblanched and either solar- and freeze dried as compared to blanched leaves. The authors noted leaching of phenolic compounds may have contributed to reduced antioxidant activity for blanched and dried leafy vegetables.

\section{CONClusion}

The present study indicates solar drying is the better option over oven drying for preserving the nutritional and phytochemical composition of chia leaves albeit at different stages of growth. This is because, minimal losses in total phenolics, and improved antioxidant activity compared to fresh leaves were better in solar drying. The simplicity of solar drying is a convenient option due to low-cost technology and ease of adoption. Oven-drying whilst taking shorter time to dry the chia leaves, has high operating costs and consequently low adoption. However, while the present study shows chia leaves are viable alternatives food sources, there is need for further investigation on optimum drying techniques and temperatures of chia leaves necessary for food and nutrition security.

\section{ACKNOWLEDGMENT}

The author thanks the supervisor and laboratory technicians in the Department of Institute of Food Bioresources Technology, Dedan Kimathi University and Coffee research Institute, Ruiru. The author also thanks the family members for the support and prayers throughout the study.

\section{REFERENCES}

[1] Kunyanga CN, Imungi JK, Okoth MW, Biesalski HK, Vadivel V. Total phenolic content, antioxidant and antidiabetic properties of methanolic extract of raw and traditionally processed Kenyan indigenous food ingredients. LWT-Food Science and Technology. 2012 Mar 1;45(2):269-76.doi:10.1016/j.lwt.2011.08.006.

[2] Amato M, Caruso MC, Guzzo F, Galgano F, Commisso M, Bochicchio R, Labella R, Favati F. Nutritional quality of seeds and leaf metabolites of Chia (Salvia hispanica L.) from Southern Italy. European Food Research and Technology. 2015 Nov;241(5):61525.doi:10.1007/s00217-015-2488-9.

[3] Bochicchio R, Philips TD, Lovelli S, Labella R, Galgano F, Di Marisco A, Perniola M, Amato M. Innovative crop productions for healthy food: the case of chia (Salvia hispanica L.). The sustainability of agro-food and natural resource systems in the Mediterranean basin.Springer. 2015 Apr 24:29-45.

[4] Muñoz LA, Cobos A, Diaz O, Aguilera JM. Chia seed (Salvia hispanica): an ancient grain and a new functional food. Food reviews international. 2013 Oct 2;29(4):394-408. doi:10.1080/87559129.2013.818014.

[5] Maseko I, Mabhaudhi T, Ncube B, Tesfay S, Araya HT, Fessehazion MK, Chimonyo VG, Ndhlala AR, Du Plooy CP. Postharvest drying maintains phenolic, flavonoid and gallotannin content of some cultivated African leafy vegetables. Scientia Horticulturae. 2019 Sep 20;255:70-6.doi: 10.1016/j.scienta.2019.05.019.

[6] Deng LZ, Mujumdar AS, Zhang Q, Yang XH, Wang J, Zheng ZA, Gao ZJ, Xiao HW. Chemical and physical pretreatments of fruits and vegetables: Effects on drying characteristics and quality attributes-a 
comprehensive review. Critical reviews in food science and nutrition. 2019 May 15;59(9):1408-32.doi:10.1080/10408398.2017.1409192.

[7] Zhang M, Chen H, Mujumdar AS, Tang J, Miao S, Wang Y. Recent developments in high-quality drying of vegetables, fruits, and aquatic products. Critical reviews in food science and nutrition. 2017 Apr 13;57(6):1239-55.doi:10.1080/10408398.2014.979280.

[8] Mujuka E, Ambuko J, Mburu J, Ogutu A. Investment in Postharvest Technologies: Key Strategy for Postharvest Loss Reduction. Kenya Policy Briefs. 2021 Feb 26;2(1):47-8.

[9] Putriani N, Perdana J, Meiliana, Nugrahedi PY. Effect of Thermal Processing on Key Phytochemical Compounds in Green Leafy Vegetables: A Review. Food Reviews International. 2020 Apr 18:129.doi:10.1080/87559129.2020.1745826.

[10] Managa MG, Sultanbawa Y, Sivakumar D. Effects of different drying methods on untargeted phenolic metabolites, and antioxidant activity in Chinese cabbage (Brassica rapa L. subsp. chinensis) and nightshade

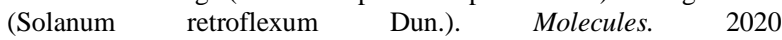
Jan;25(6):1326.doi:10.3390/molecules25061326.

[11] Mbondo NN, Owino WO, Ambuko J, Sila DN. Effect of drying methods on the retention of bioactive compounds in African eggplant. Food science \& nutrition. 2018 Jun;6(4):814-23.doi: 10.1002/fsn3.623.

[12] Fernandes SS, Romani VP, da Silva Filipini G, G Martins V. Chia seeds to develop new biodegradable polymers for food packaging: Properties and biodegradability. Polymer Engineering \& Science. 2020 Sep;60(9):2214-23. doi:10.1002/pen.25464.

[13] Timilsena YP, Adhikari R, Barrow CJ, Adhikari B. Physicochemical and functional properties of protein isolate produced from Australian chia seeds. Food chemistry. 2016 Dec 1;212:648-56. doi:10.1016/j.foodchem.2016.06.017.

[14] Mehlomakulu NN, Emmambux MN. Nutritional Quality of Wet and Dry Processed Moringa oleifera Lam. Leaves: A Review. Food Reviews International. 2020 Oct 17;1-21.

[15] Cheptoo G, Owino W, Kenji G. Nutritional quality, bioactive compounds and antioxidant activity of selected african indigenous leafy vegetables as influenced by maturity and minimal processing. African Journal of Food, Agriculture, Nutrition and Development. 2019 Nov 4;19(3):14769-89. doi:10.18697/ajfand.86.17835.

[16] Kirakou SP, Hutchinson MJ, Ambuko J, Owino WO. Efficacy of blanching techniques and solar drying in maintaining the quality attributes of cowpea leaves. African Journal of Horticultural Science. 2017 Aug 1;11:18-34.

[17] Alibas I, Yilmaz A, Asik BB, Erdoğan H. Influence of drying methods on the nutrients, protein content and vitamin profile of basil leaves. Journal of Food Composition and Analysis. 2021 Mar 1;96:103758. doi:10.1016/j.jfca.2020.103758.

[18] Traoré K, Parkouda C, Savadogo A, Ba/Hama F, Kamga R, Traoré Y. Effect of processing methods on the nutritional content of three traditional vegetables leaves: Amaranth, black nightshade and jute mallow. Food science \& nutrition. 2017 Nov;5(6):113944.doi:10.1002/fsn3.504.

[19] Obembe OM, Ojo DO, Ileke KD. Effect of different drying methods and storage on proximate and mineral composition of fluted pumpkin leaf, Telfairia occidentalis Hook f. Journal of Horticulture and Postharvest Research. 2021 Jun 1;4(2-June 2021):14150.doi:10.22077/JHPR.2020.3414.1145.

[20] Umerah NN, Asouzu AI, Okoye JI. Effect of processing on the nutritional composition of Moringa olifera Leaves and Seeds. European Journal of Nutrition \& Food Safety. 2019 Dec 6:12435.doi:10.9734/ejnfs/2019/v11i330155.

[21] Moyo SM, Mavumengwana V, Kayitesi E. Effects of cooking and drying on phenolic compounds and antioxidant activity of African green leafy vegetables. Food reviews international. $2018 \mathrm{Apr}$ 3;34(3):248-64.doi:10.1080/87559129.2017.1289384.

[22] Shonte TT, Duodu KG, de Kock HL. Effect of drying methods on chemical composition and antioxidant activity of underutilized stinging nettle leaves. Heliyon. 2020 May 1;6(5):e03938.doi: 10.1016/j.heliyon.2020.e03938. 